\title{
Efficiency and response of conilon coffee clones to phosphorus fertilization ${ }^{1}$
}

\author{
Lima Deleon Martins ${ }^{2}$, Marcelo Antonio Tomaz ${ }^{3}$, José Francisco Teixeira do Amaral, \\ Scheilla Marina Bragança ${ }^{5}$,Herminia Emilia Prieto Martinez ${ }^{6}$
}

\begin{abstract}
Studies on nutritional efficiency of phosphorus in conilon coffee plants are important tools to unravel the high limitation that natural low levels of this nutrient in soil impose to these species cultivars. Therefore, this study aimed at evaluating the nutritional efficiency and the response to phosphorus of conilon coffee clones. Plants were managed during 150 days in pots containing $10 \mathrm{dm}^{3}$ of soil, in greenhouse. A factorial scheme $13 \times 2$ was used, with three replications, being the factors: 13 clones constituting the clonal cultivar "Vitória Incaper 8142" and two levels of phosphate fertilization ( $0 \%$ and $150 \%$ of the $\mathrm{P}_{2} \mathrm{O}_{5}$ usualy recommended), in a completely randomized design (CRD). The results indicate a differentiated response of dry matter production and of phosphorus content on each level of phosphate fertilization for the conilon coffee clones and that CV-04, CV-05 and CV-08 clones are nutritionally efficient and responsive to the phosphate fertilization.
\end{abstract}

Key words: Coffea canephora (Pierre ex A. Froehner), mineral nutrition, alpha parameter.

\section{RESUMO}

\section{Eficiência e resposta de clones de cafeeiro conilon ao fósforo}

Estudos de eficiência nutricional de fósforo, em cafeeiro conilon, são ferramentas importantes para contornar a elevada limitação que os baixos níveis naturais desse nutriente trazem aos cultivares dessa espécie. Objetivou-se, com este trabalho, estudar a eficiência nutricional e a resposta ao fósforo por clones de cafeeiro conilon. As plantas foram conduzidas durante 150 dias em vasos, contendo $10 \mathrm{dm}^{3}$ de solo, em casa de vegetação. Utilizou-se o esquema fatorial 13 x 2, com três repetições, sendo os fatores: 13 clones que compõem o cultivar clonal "Vitória Incaper 8142" e dois níveis de adubação fosfatada ( 0 e $150 \%$ do recomendado de $\mathrm{P}_{2} \mathrm{O}_{5}$ para a cultura), em delineamento inteiramente casualizado. Os resultados indicam resposta diferenciada de produção de massa de matéria seca e de conteúdo de fósforo a cada nível de adubação fosfatada, para os clones de cafeeiro conilon e que os clones CV-04, CV-05 e CV-08 apresentam-se nutricionalmente eficientes e responsivos à adubação fosfatada.

Palavras-chave: Coffea canephora Pierre ex A. Froehner, nutrição mineral, parâmetro alfa.

\footnotetext{
Received on March 14 $4^{\text {th }}, 2012$ and approved on March 06 $6^{\text {th }}, 2013$.

${ }^{1}$ Part of the first author Master's thesis presented to the Graduate Program of CCA/UFES.

${ }^{2}$ Agronomist engineer, Master of Science. Departamento de Produção Vegetal, Universidade Federal do Espírito Santo, Alto Universitário, s/n, 29500-000, Alegre, Espírito Santo, Brasil. deleon_lima@ hotmail.com

${ }^{3}$ Agronomist engineer, Doctor of Science. Departamento de Produção Vegetal, Universidade Federal do Espírito Santo, Alto Universitário s/n, 29500-000, Alegre, Espírito Santo, Brasil.tomaz@cca.ufes.br

${ }^{4}$ Agronomist engineer, Doctor of Science. Departamento de Engenharia Rural, Universidade Federal do Espírito Santo, Alto Universitário s/n, 29500-000, Alegre, Espírito Santo, Brasil.jfamaral@cca.ufes.br

${ }^{5}$ Agronomist engineer, Doctor of Science. INCAPER, BR 101, Km 151, Caixa Postal 62, 29915-140, Linhares, Espírito Santo, Brasil. bragancasm@uol.com.br

${ }^{6}$ Agronomist engineer, Doctor of Science. Departamento de Fitotecnia, Universidade Federal de Viçosa, Campus Viçosa, Avenida Peter Henry Rolfs, s/n, 36570-000, Viçosa, Minas Gerais, Brasil. herminia@ufv.br
}

Rev. Ceres, Viçosa, v. 60, n.3, p. 406-411, mai/jun, 2013 


\section{INTRODUCTION}

The coffee plant crop has expanded to extensive areas with natural low fertility (Amaral et al., 2011), mainly related to phosphorus (P). Such agricultural frontier advance has evidenced a difficulty in handling, the cultivar fertilization, due to the high limitation in biomass and coffee bean productivity caused by P shortage in Brazilian soil (Novais et al., 2007). Such combination made recurrent the use of phosphate fertilizer, increasing production costs and knowledge needs to mitigate the situation.

Although literature presents relevant information on growth, development and nutrition of the coffee plant crop (Fonseca et al., 2004; DaMatta et al., 2007; Ferrão et al., 2008; Bragança et al., 2010), little is known about the crop nutritional efficiency.

The concept of nutritional efficiency is applied aiming at characterizing the plants regarding its capacity of nutrient absorption and usage, an extremely important concept to the investigation of genotypes with potential to adapt to limited nutritional conditions (Machado et al. 2004; Tomaz et al., 2011).

The main solution given, of a preventive aspect, for the increase in productivity and decrease on fertilizer usage is the selection of tolerant genotypes adapted to low nutrient availability; another one, the adequacy of nutritional levels to make the crop more nutritionally efficient (Silva et al., 2010; Amaral et al., 2012). Such tolerance is associated to the efficiency on absorption and usage of nutrients for biomass production, a fundamental aspect for the adaptation of the plants to soils limited in terms of fertility (Lana et al., 2006; Rotili et al., 2010).

An efficient plant on using phosphorus developing in an environment with insufficient availability of the nutrient for maximum productivity, producing high quantity of dry matter per unit of time and area (Fox, 1978).

According to Fageria (1998), there is a genetic variation related to phosphorus nutritional efficiency of genotypes of the same species. On the above, studies seeking to understand phosphorus nutrition of the coffee plant are essential, aiming at establishing initial criteria allowing for the maximization of P nutritional efficiency.

On studies about mineral nutrition, parameters must be used that not only measure nutritional efficiency but also helps obtaining indices of genotypes response to the nutrient application. Accordingly, it is important to apply the alfa $(\alpha)$ parameter which is an estimator of nutritional efficiency and of the response to the fertilization (Fox, 1978).

For this reason, the objective of the present work was to study the nutritional efficiency and the response to phosphorus of conilon coffee clones constituting the clonal cultivar "Vitória Incaper 8142".

\section{MATERIALS AND METHODS}

The experiment was conducted in greenhouse in the experimental area of the Centro de Ciências Agrárias of the Universidade Federal do Espírito Santo (CCA-UFES), located at Alegre municipality - ES, with a latitude of $20^{\circ} 45^{\prime}$ $\mathrm{S}$, a longitude of $41^{\circ} 33^{\prime} \mathrm{W}$ and altitude of $277,41 \mathrm{~m}$. The soil used was collected at the experimental research area of the CCA-UFES, at 10 to $40 \mathrm{~cm}$ depth, eliminating the first $10 \mathrm{~cm}$ of the soil profile to decrease the effect of organic matter of this superficial layer. A sample was forwarded to chemical and physical analysis (Table 1), further characterized as dystrophic red-yellow clay loam LVAarg (Embrapa, 1997).

The entire soil volume was dried in shadow, homogenized using a $2.0 \mathrm{~mm}$ mesh sieve and separated in samples of $10 \mathrm{dm}^{3}$ volume by weighting in precision balance and packed in 14 liter sealed plastic pots.

The experiment was set up using a $13 \times 2$ factorial distribution with 3 replications, being the factors: 13 clones of the clonal cultivar "Vitória Incaper 8142" (CV-01, CV02, CV-03, CV-04, CV-05, CV-06, CV-07, CV-08, CV-09, CV$10, \mathrm{CV}-11, \mathrm{CV}-12$ e CV-13) and two levels of phosphate fertilization $\left(0 \%\right.$ and $150 \%$ of the $\mathrm{P}_{2} \mathrm{O}_{5}$ recommended according to Lani et al., 2007), in a completely randomized design (CRD), being each experimental unity constituted by a seedling of each genotype per pot.

Table 1. Physical and chemical characteristic of the soil used as substrate

\begin{tabular}{|c|c|}
\hline Characteristics & LVAarg \\
\hline$\overline{\text { Coarse sand }\left(\mathrm{g} \mathrm{kg}^{-1}\right)^{1}}$ & 395.30 \\
\hline Fine sand $\left(\mathrm{g} \mathrm{kg}^{-1}\right)^{1}$ & 157.70 \\
\hline Silt $\left(\mathrm{g} \mathrm{kg}^{-1}\right)^{1}$ & 43.60 \\
\hline Clay $\left(\mathrm{g} \mathrm{kg}^{-1}\right)^{1}$ & 403.40 \\
\hline Soil density $\left(\mathrm{kg} \mathrm{dm}^{-3}\right)^{2}$ & 1.20 \\
\hline $\mathrm{pH}^{3}$ & 5.40 \\
\hline $\left.\mathrm{P}(\mathrm{mg} \mathrm{dm})^{-3}\right)^{4}$ & 2.00 \\
\hline $\mathrm{K}\left(\mathrm{mg} \mathrm{dm}^{-3}\right)^{5}$ & 93.0 \\
\hline $\mathrm{Ca}\left(\mathrm{cmol}_{\mathrm{c}} \mathrm{dm}^{-3}\right)^{6}$ & 1.70 \\
\hline $\operatorname{Mg}\left(\mathrm{cmol}_{\mathrm{c}} \mathrm{dm}^{-3}\right)^{6}$ & 1.10 \\
\hline $\mathrm{Al}\left(\mathrm{cmol}_{\mathrm{c}} \mathrm{dm}^{-3}\right)^{6}$ & 0.00 \\
\hline $\mathrm{H}+\mathrm{Al}\left(\mathrm{cmol}_{\mathrm{c}} \mathrm{dm}^{-3}\right)^{6}$ & 2.10 \\
\hline Organic matter $\left(\mathrm{g} \mathrm{kg}^{-1}\right)^{7}$ & 19.10 \\
\hline Sum of bases $\left(\mathrm{cmol}_{\mathrm{c}} \mathrm{dm}^{-3}\right)$ & 3.37 \\
\hline CEC potencial $\left(\mathrm{cmol}_{\mathrm{c}} \mathrm{dm}^{-3}\right)$ & 5.45 \\
\hline CEC effective $\left(\mathrm{cmol}_{\mathrm{c}} \mathrm{dm}^{-3}\right)$ & 3.37 \\
\hline Saturation per bases $(\%)$ & 61.80 \\
\hline Saturation per aluminum $(\%)$ & 0.00 \\
\hline
\end{tabular}

1. Pipette method (slow mixing); ${ }^{2}$ Graduated cylinder method; ${ }^{3} \cdot \mathrm{pH}$ in water (relation 1:2.5); ${ }^{4}$ Extracted by Mehlich 1 and determined by colorimetry; ${ }^{5}$. Extracted by Mehlich 1 and determined by flame photometry; ${ }^{6}$ Extracted with $1 \mathrm{~mol} \mathrm{~L}^{-1}$ potassium chloride and determined by titration; ${ }^{7}$ Extracted by oxidation, humid route, with potassium dichromate in sulfuric medium and determined by titration (Embrapa, 1997). 
Levels of P used in the study were chosen based on recommendations for conilon coffee crop proposed by Lani et al. (2007), using zero level as control and the $150 \%$ level aiming at effectively differentiating the response to $\mathrm{P}$ besides nutritional efficiency. For this, $9.45 \mathrm{~g}$ of $\mathrm{P}_{2} \mathrm{O}_{5} /$ pot was applied in the form of salt p.a. $\left(\mathrm{KH}_{2} \mathrm{PO}_{4}\right)$, diluted in distilled water and totally homogenized into the soil volume of the pot.

After $\mathrm{P}_{2} \mathrm{O}_{5}$ application, conilon coffee seedlings provided by Instituto Capixaba de Pesquisa, Assistência Técnica e Extensão Rural - INCAPER, produced at Fazenda Experimental de Marilândia-ES, were seeded (120 days of development with two pairs of leaves and good phytosanitary and nutritional aspects).

The amount of potassium provided to all experimental units was $5.20 \mathrm{~g} \mathrm{~K}_{2} \mathrm{O} /$ pot, where, for treatments without fertilization with $\mathrm{P}\left(\mathrm{KH}_{2} \mathrm{PO}_{4}\right.$ p.a. $)$, potassium fertilization was done with the addition of $\mathrm{KCl}$ p.a., diluted in distilled water and totally homogenized to the soil volume in the pot during planting.

Nitrogen fertilization with $\mathrm{NH}_{2} \mathrm{CONH}_{2}$ p.a. was conducted according to Lani et al. (2007). Nitrogen diluted in distilled water was applied on the surface in circles, 10 $\mathrm{cm}$ away from the plant crown, with the fertilization $(17.3 \mathrm{~g}$ of nitrogen per pot) divided into five applications: the first one on the first day and the others periodically at 30 , 60, 90 and 120 days after planting.

At 150 days of cultivation, plants were cut, separating the stem from the branches, leaves and roots. These parts were removed from the pots, washed, weighted and dried in shadow, further separately packed in paper bags and taken to stove with forced air circulation at a temperature of $65^{\circ} \mathrm{C}$ until a constant weight was obtained to determine the dry matter.

To determine the shoot dry matter (SDM) and the root dry matter (RDM), the material was weighted on an analytical precision balance, obtaining results on grams per plant. As SDM is the sum of the dry matter weight of leaves, stem and branches, total dry matter (TDM) was obtained by the sum of the SDM to the RDM.

\section{$\alpha$ parameter $=\underline{(S D M \text { at } 150 \% \text { level }- \text { SDM at } 0 \% \text { level })}$ Difference on the applied $P$ levels}

The determination of $\mathrm{P}$ content in the root, shoot (stem plus branches) and leaves in experimental units were done according to methods described by Embrapa (1997). The á parameter was calculated as reported by Fox (1978) in order to classify clones according to nutritional efficiency and response to phosphate fertilization with the equation:

For such calculation, SDM mean values were used, corresponding to control and $150 \%$ phosphate fertilization. Difference between phosphate levels was 9.45 $\mathrm{g} /$ pot, by subtracting $\mathrm{P}_{2} \mathrm{O}_{5}$ quantity applied on the soil of the portion related to the $0 \%$ level $(0 \mathrm{~g} / \mathrm{pot})$ from the one with the recommended $\mathrm{P}_{2} \mathrm{O}_{5}$ level of $150 \%$ (9.45 g/pot).

The $\alpha$ parameter results of each clone were arranged in quadrants together with mean SDM values, related to the reference level. Genotypes were then classified according to 4 groups: ER - efficient and responsive clones; ENR - efficient and non-responsive clones; NER - non-efficient and responsive clones; NENR - nonefficient and non-responsive clones.

Data was subjected to analysis of variance $(\mathrm{p} \leq 0.05)$, using SISVAR statistic software (Ferreira, 2008) and, when the sources of variation were significant, Tukey test ( $\mathrm{p} \leq$ 0.05) was used to compare phosphate levels for each conilon coffee clone and Scott-Knott test $(\mathrm{p} \leq 0.05)$ to compare clones inside each phosphate level.

\section{RESULTS AND DISCUSSION}

Altogether, it can be verified in table 2, comparing each clone for P levels that the greatests SDM, RDM and TDM productions were obtained in high phosphate level (P2).

This is due to the fact that the $\mathrm{P}$ available in the soil maximizes the photosynthetic performance, inducing a greater stomatal opening and a greater biochemical and photochemical activity in the coffee plant, what will provide greater energy availability as carbohydrates for the plant. Results that show the relation previously cited were found on arabica coffee plant by Silva et al. (2010), which showed that the greater phosphorus availability in the soil promoted high dry matter production and was linked to the greater capacity of light capture and stomatal opening.

Low phosphorus availability in the soil must also be noted that became evident by the decrease on total dry matter of coffee plant clones, confirming some literature data (Critchley, 1998; Shubhra et al., 2004; Torres Netto et al., 2005; Silva et al., 2010), showing that TDM decrease is associated to a lower stomatal conductivity and, consequently, low $\mathrm{CO}_{2}$ absorption; lower light capture (resulted from a FSII degradation), resulting on the decrease on photosynthetic pigment content, and also, reduced electron transport rate that influences for the lower NADPH production.

Similar results with jatropha were reported by Amaral et al. (2012), that found greater vegetative development, dry matter accumulation, content and efficiency of absorption and $\mathrm{P}$ translocation in the high level of available $\mathrm{P}$ in the soil.

The analysis of the shoot dry matter (SDM) mean values of the 13 conilon coffee clones presents the formation of 7 different mean groups on low phosphorus 
level (P1) and of 5 mean groups, significantly different, on high phosphorus level (P2). For RDM mean values, the formation of 5 different mean groups on low phosphorus level and 7 different mean groups, on high phosphorus level occurred. Regarding TDM, the formation of 8 mean groups was verified for low level and of 6 different mean groups for the superior level of phosphorus recommended for the crop (Table 2).

It can be noted that conilon coffee clones present different responses of dry matter production (RDM, SDM and TDM) in each level of phosphate fertilization. Fageria (1999) stated that, commonly, different dry matter production is observed under the same soil fertility condition for cultivars from the same species. According to Amaral et al. (2011), such differences are genetically determined and controlled by various characteristics, which are related to nutrient absorption, transport and usage by plants of the same species.

Thereby, results of the present study may be justified by genetic and phenotypic variability in conilon coffee clones, respectively described by Ferrão et al. (2008) and Fonseca et al. (2004). Studying 40 genetic parameters of conilon coffee clones, Ferrão et al. (2008) reported a wide genetic variability between genotypes. Fonseca et al. (2004), studying 8 production cycles, reported that conilon coffee clones, constituting the clonal cultivar "Vitória Incaper 8142", present wide phenotypic variability.

Similarly to dry matter mean values, it can be seen for all conilon coffee clones in high phosphorus level, statistically higher mean values of $\mathrm{P}$ content in the shoot part (CSP), root (CR) and total (CT) (Table 3). According to Novais et al. (2007), different phosphorus concentration in the soil may affect its content in the plant, what will influence growth rate, biomass partition between root and shoot and the $\mathrm{P}$ absorption rate per root unity.

Studying P content mean values of conilon coffee clones in each phosphorus level, the formation of 5 different groups of mean values of phosphorus in the shoot part, root and total was verified, in the lower phosphorus level. In phosphorus higher level, the formation of 6 mean groups occurred, statistically different, according to phosphorus content in the roots and seven different groups in relation to phosphorus total content (Table 3 ).

It can be noted that $\mathrm{CV}-09$, in the lower phosphorus level in the soil (P1), settled on the higher mean group for all variables of dry matter mass and $\mathrm{P}$ content, showing the capacity of this clone to adapt to phosphorus soil deficiency, i.e., CV-09 clone presented a potential efficiency on $\mathrm{P}$ absorption and translocation.

On the contrary, CV-11 presented lower results comparing to the others, making it possible to infer that it presents low adaptability to soils poor in phosphorus, what characterizes a low nutritional efficiency related to $\mathrm{P}$ (Table 2 and 3 ).

It was verified that conilon coffee clones present different $\mathrm{P}$ content in their dry biomass. This distinction between genotypes of the same species can be caused by the root system morphology, by the ratio between root and shoot and by the root's distribution, architecture and diameter (Amaral et al., 2011). This difference in P content in conilon coffee clones' dry matter may influence the phosphorus nutritional efficiency. Studying the efficiency on phosphorus absorption and usage in corn, Machado et al. (2004) found high correlation between P content in plant and phosphorus absorption efficiency.

Table 2. Mean values of shoot (SDM), root (RDM) and total (TDM) dry matter mass (g/plant) of conilon coffee clones constituting "Vitória Incaper 8142" cultivar in two levels of phosphorus (0 and 150\% of the recommended values for the crop, respectively P1 and P2)

\begin{tabular}{|c|c|c|c|c|c|c|}
\hline \multirow{2}{*}{ Clones } & \multicolumn{2}{|c|}{ SDM } & \multicolumn{2}{|c|}{ RDM } & \multicolumn{2}{|c|}{ TDM } \\
\hline & P1 & $\mathbf{P 2}$ & P1 & $\mathbf{P 2}$ & P1 & $\mathbf{P 2}$ \\
\hline CV-01 & $34.07 \mathrm{bB}$ & $63.44 \mathrm{cA}$ & $7.37 \mathrm{cB}$ & $16.10 \mathrm{gA}$ & $41.41 \mathrm{bB}$ & $79.65 \mathrm{fA}$ \\
\hline CV-02 & $22.94 \mathrm{fB}$ & $52.06 \mathrm{eA}$ & $7.33 \mathrm{cB}$ & $19.40 \mathrm{fA}$ & $31.42 \mathrm{eB}$ & $71.43 \mathrm{gA}$ \\
\hline CV-03 & $28.59 \mathrm{~dB}$ & $62.30 \mathrm{cA}$ & $6.10 \mathrm{~dB}$ & $29.91 \mathrm{aA}$ & $34.71 \mathrm{~dB}$ & $92.03 \mathrm{cA}$ \\
\hline CV-04 & $26,83 \mathrm{eB}$ & $63.69 \mathrm{cA}$ & $5.57 \mathrm{~dB}$ & $16.44 \mathrm{gA}$ & $32.39 \mathrm{eB}$ & $80.13 \mathrm{fA}$ \\
\hline CV-05 & $27.73 \mathrm{~dB}$ & $65.34 \mathrm{bA}$ & $9.67 \mathrm{bB}$ & $28.66 \mathrm{bA}$ & $37.38 \mathrm{cB}$ & $93.62 \mathrm{bA}$ \\
\hline CV-06 & $26.34 \mathrm{eB}$ & $69.61 \mathrm{aA}$ & $5.73 \mathrm{~dB}$ & $20.78 \mathrm{eA}$ & $32.06 \mathrm{eB}$ & $90.59 \mathrm{cA}$ \\
\hline CV-07 & $31.35 \mathrm{cB}$ & $66.72 \mathrm{bA}$ & $9.27 \mathrm{bB}$ & $30.04 \mathrm{aA}$ & $40.74 \mathrm{bB}$ & $96.97 \mathrm{aA}$ \\
\hline CV-08 & $29.97 \mathrm{cB}$ & $65.49 \mathrm{bA}$ & $8.30 \mathrm{cB}$ & $24.45 \mathrm{dA}$ & $38.33 \mathrm{cB}$ & $90.03 \mathrm{cA}$ \\
\hline CV-09 & $38.63 \mathrm{aB}$ & $60.93 \mathrm{dA}$ & $11.4 \mathrm{aB}$ & $26.71 \mathrm{cA}$ & $50.05 \mathrm{aB}$ & $87.50 \mathrm{dA}$ \\
\hline CV-10 & $26.33 \mathrm{eB}$ & $63.25 \mathrm{cA}$ & $5.47 \mathrm{~dB}$ & $22.33 \mathrm{eA}$ & $29.37 \mathrm{fB}$ & $85.47 \mathrm{eA}$ \\
\hline CV-11 & $18.93 \mathrm{gB}$ & $62.71 \mathrm{cA}$ & $1.73 \mathrm{eB}$ & $25.69 \mathrm{cA}$ & $20.59 \mathrm{hB}$ & $88.12 \mathrm{dA}$ \\
\hline CV-12 & $23.65 \mathrm{fB}$ & $64.17 \mathrm{cA}$ & $2.43 \mathrm{eB}$ & $19.48 \mathrm{fA}$ & $26.07 \mathrm{gB}$ & $83.51 \mathrm{eA}$ \\
\hline CV-13 & $24.91 \mathrm{eB}$ & $60.56 \mathrm{dA}$ & $4.40 \mathrm{~dB}$ & $23.80 \mathrm{dA}$ & $29.37 \mathrm{fB}$ & $84.46 \mathrm{eA}$ \\
\hline
\end{tabular}

Means followed by the same letter in each variable, uppercase letters in lines (Tukey) and lowercase letters in columns (Scott-Knott), are not different $(\mathrm{p} \leq 0.05)$. 
Figure 1 presents the nutritional efficiency and response of conilon coffee clones, related to the levels of 0 and $150 \%$ of the recommended $\mathrm{P}_{2} \mathrm{O}_{5}$, according to the concept proposed by Fox (1978).

CV-04, CV-05 and CV-08 clones behaved as nutritionally efficient and responsive (ER). Clones characterized as ER are those producing the most in conditions of low phosphorus content in the soil and, also, responded to the increase of this element in the soil. Similar results were found by Amaral et al. (2012), studying jatropha, where the authors observed that the alfa parameter was effective to differentiate genotypes nutritionally efficient and responsive to $\mathrm{P}$, where the classification of the jatropha access as ER was linked to the high dry matter value, as well as a reduced value of total $\mathrm{P}$ content, maximizing the index of $\mathrm{P}$ usage efficiency.

Now, the conilon coffee clones CV-06, CV-10, CV-11 and $\mathrm{CV}-12$ were classified as non-efficient and responsive (NER). Although they have responded well to the increase in phosphorus level, they did not reach dry matter mass production of the clones classified as ER and ENR in phosphorus low level.

CV-01, CV-03, CV-07 and CV-09 clones are grouped in the quadrant that classifies clones as nutritionally efficient

Table 3. Mean values of P content (mg/planta) of the shoot part (CSP), root (CR) and total (CT) of conilon coffee clones constituting the "Vitória Incaper 8142 " cultivar, in two levels of phosphorus ( 0 and $150 \%$ of the recommended values for the crop, respectively $\mathrm{P} 1$ and $\mathrm{P} 2)$

\begin{tabular}{|c|c|c|c|c|c|c|}
\hline \multirow{2}{*}{ Clones } & \multicolumn{2}{|c|}{ CSP } & \multicolumn{2}{|c|}{ CR } & \multicolumn{2}{|c|}{ CT } \\
\hline & P1 & $\mathbf{P 2}$ & P1 & $\mathbf{P 2}$ & P1 & $\mathbf{P 2}$ \\
\hline CV-01 & $35.54 \mathrm{bB}$ & $102.43 \mathrm{eA}$ & $6.45 \mathrm{cA}$ & $20.93 \mathrm{hA}$ & $42.00 \mathrm{bB}$ & $123.37 \mathrm{fA}$ \\
\hline $\mathrm{CV}-02$ & $32.46 \mathrm{bB}$ & $89.80 \mathrm{fA}$ & $8.16 \mathrm{bA}$ & $29.35 \mathrm{eA}$ & $40.62 \mathrm{bB}$ & $119.15 \mathrm{gA}$ \\
\hline CV-03 & $35.97 \mathrm{bB}$ & $118.39 \mathrm{cA}$ & $6.31 \mathrm{cA}$ & $39.50 \mathrm{bA}$ & $42.29 \mathrm{bB}$ & $157.89 \mathrm{bA}$ \\
\hline CV-04 & $33.47 \mathrm{bB}$ & $113.92 \mathrm{dA}$ & $6.18 \mathrm{cA}$ & $23.19 \mathrm{gA}$ & $39.66 \mathrm{bB}$ & $137.11 \mathrm{eA}$ \\
\hline CV-05 & $29.41 \mathrm{cB}$ & $120.64 \mathrm{bA}$ & $9.17 \mathrm{bA}$ & $45.34 \mathrm{aA}$ & $38.59 \mathrm{bB}$ & $165.99 \mathrm{aA}$ \\
\hline CV-06 & $27.70 \mathrm{cB}$ & $126.67 \mathrm{aA}$ & $0.89 \mathrm{eA}$ & $21.43 \mathrm{hA}$ & $28.59 \mathrm{~dB}$ & $148.10 \mathrm{dA}$ \\
\hline CV-07 & $34.01 \mathrm{bB}$ & $117.74 \mathrm{cA}$ & $9.52 \mathrm{bA}$ & $43.81 \mathrm{aA}$ & $43.54 \mathrm{bB}$ & $161.55 \mathrm{bA}$ \\
\hline CV-08 & $31.40 \mathrm{bB}$ & $105.43 \mathrm{eA}$ & $9.27 \mathrm{bA}$ & $30.37 \mathrm{dA}$ & $40.67 \mathrm{bB}$ & $135.80 \mathrm{eA}$ \\
\hline CV-09 & $40.52 \mathrm{aB}$ & $120.21 \mathrm{bA}$ & $11.0 \mathrm{aA}$ & $40.14 \mathrm{bA}$ & $51.54 \mathrm{aB}$ & $160.36 \mathrm{bA}$ \\
\hline CV-10 & $24.32 \mathrm{~dB}$ & $120.96 \mathrm{bA}$ & $1.97 \mathrm{eA}$ & $28.69 \mathrm{eA}$ & $26.29 \mathrm{~dB}$ & $149.66 \mathrm{cA}$ \\
\hline CV-11 & $20.11 \mathrm{eB}$ & $114.84 \mathrm{dA}$ & $1.37 \mathrm{eA}$ & $36.91 \mathrm{cA}$ & $21.49 \mathrm{eB}$ & $151.76 \mathrm{cA}$ \\
\hline CV-12 & $25.32 \mathrm{~dB}$ & $120.32 \mathrm{bA}$ & 0.89 eA & $25.00 \mathrm{fA}$ & $26.22 \mathrm{~dB}$ & $145.33 \mathrm{dA}$ \\
\hline CV-13 & $29.59 \mathrm{cB}$ & $116.00 \mathrm{dA}$ & $4.07 \mathrm{dA}$ & $31.30 \mathrm{dA}$ & $33.67 \mathrm{cB}$ & $147.31 \mathrm{dA}$ \\
\hline
\end{tabular}

Means followed by the same letter in each variable, uppercase letters in lines (Tukey) and lowercase letters in columns (Scott-Knott), are not different $(\mathrm{p} \leq 0.05)$.

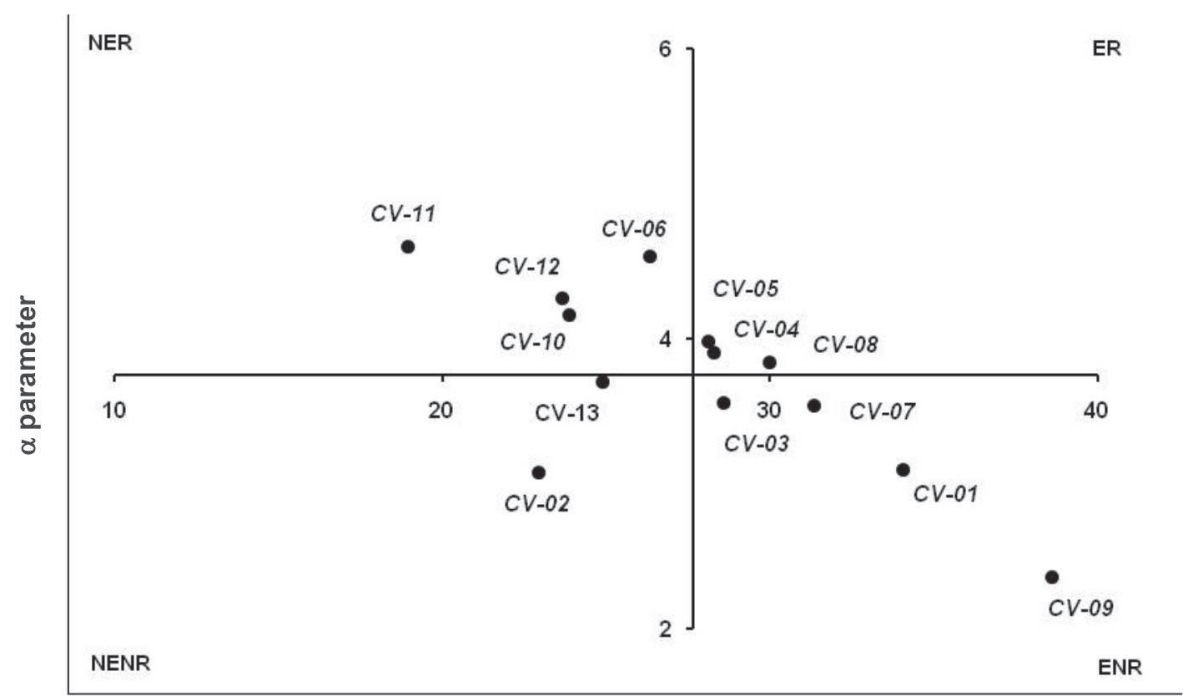

Shoot dry matter mass $\left(0 \% \mathrm{P}_{2} \mathrm{O}_{5}\right)$

Figure 1. Classification of conilon coffee clones according to nutritional efficiency and response to phosphate fertilization. ER $=$ efficient and responsive; ENR = efficient and non-responsive; NER = non-efficient and responsive; and NENR = non-efficient and non-responsive.

Rev. Ceres, Viçosa, v. 60, n.3, p. 406-411, mai/jun, 2013 
and non-responsive (ENR), , making it possible to infer that, although they have a significant production in phosphorus low level, they respond less to the increase in soil phosphorus supply. CV-02 and CV-13 clones were classified as nutritionally non-efficient and non-responsive for the low matter mass production of the shoot part.

In literature, the study parameter of nutritional efficiency and response to nutrients by different genotypes, proposed by Fox (1978) is widely used, as cited by Fageria (1998), Lana et al. (2006) and Rotili et al. (2010); however, there is no consensus on what index of nutritional efficiency represents the greatest influence.

According to Lana et al. (2006), P translocation efficiency was the one that mostly influenced bean response and, according to Rotili et al. (2010), efficiency on phosphorus usage presented greater influence on the response of rice varieties cultivated in irrigated lowland soil.

Overall, Fageria (1998) reported a positive correlation between all forms of nutritional efficiency studies regarding the responsiveness of genotypes of the same species to nutritional stress. However, the author considers that, in conditions of soil in Brazil, improving $\mathrm{P}$ absorption efficiency may be the main strategy to obtain responses related to the growth and production of crop, given the capacity of root system to adapt to adverse conditions.

\section{CONCLUSION}

Conilon coffee clones present different responses of dry matter mass production and phosphorus content in each level of phosphorus fertilization.

The conilon coffee clones CV-04, CV-05 and CV-08 presented nutritionally efficient and responsive to phosphate fertilization.

\section{ACKNOLEDGMENTS}

To Consórcio Brasileiro de Pesquisa e Desenvolvimento do Café (CBPD-Café), for the research grant. To the Graduate Program in Plant Production of Centro de Ciências Agrárias of the Universidade Federal do Espírito Santo and to the Instituto Capixaba de Pesquisa e Extensão Rural, for the support to the project. To CAPES, for the master scholarship of the first author. To CNPq for the Research Productivity Fellow of the second author.

\section{REFERENCES}

Amaral JFT, Martinez HEP, Laviola BG, Fernandes Filho EI \& Cruz CD (2011) Eficiência de utilização de nutrientes por cultivares de cafeeiro. Ciência Rural, 41:621-629.

Amaral JFT, Martins LD, Laviola BG, Christo LF, Tomaz MA \& Rodrigues WN (2012) A differential response of physic nut genotypes regarding phosphorus absorption and utilization is evidenced by a comprehensive nutrition efficiency analysis. Journal of Agricultural Science, 4:164-173.
Bragança SM, Martinez, HEP, Leite HG, Santos LP, Lani, JA, Sediyama CS \& Alvarez VH (2010) Acumulação de matéria seca pelo cafeeiro conilon. Revista Ceres, 57:48-52.

Critchley C (1998) Photoinhibition In: Raghavendra AS (Ed.) Photosynthesis: a comprehensive treatise. Cambridge, Cambridge University Press. p.264-272.

DaMatta FM, Ronchi CP, Maestri M \& Barros RS (2007) Ecophysiology of coffee growth and production. Brazilian Journal of Plant Physiology, 19:485-510.

Embrapa - Empresa Brasileira de Pesquisa Agropecuária (1997) Manual de métodos de análises e classificação de solo. $2^{a}$ ed. Rio de Janeiro, MAPA. 306p.

Fageria NK (1998) Otimização da eficiência nutricional na produção das culturas. Revista Brasileira de Engenharia Agrícola e Ambiental, 2:6-16.

Ferrão RG, Cruz CD, Ferreira A, Cecon PR, Ferrão MAG, Fonseca AFA, Carneiro, PCS \& Silva MF (2008) Parâmetros genéticos em café Conilon. Pesquisa Agropecuária Brasileira, 43:61-69.

Ferreira, DF (2008) Sisvar: um programa para análises e ensino de estatística. Revista Symposium, 6:36-41.

Fonseca AFA, Ferrão MAG, Ferrão RG, Verdin Filho AC, Volpi OS \& Zucateli F (2004) 'Conilon Vitória - Incaper 8142': improved Coffea canephora var. kouillou clone cultivar for the state of Espírito Santo. Crop Breeding and Applied Biotechnology, 4: 503-505.

Fox RH (1978) Selection for phosphorus efficiency in corn. Communications in Soil Science and Plant Analysis, 9:13-37.

Lana RMQ, Zanão LA, Correia NM \& Lana AMQ (2006) Variabilidade entre genótipos de feijoeiro na eficiência no uso do fósforo. Ciência Rural, 36:778-784.

Lani JA, Prezotti LC \& Bragança SM (2007) Cafeeiro In: Prezotti LC, Gomes JA, Dadalto GG \& Oliveira JA (Eds.) Manual de recomendação de calagem e adubação para o Estado do Espírito Santo (5 ${ }^{\text {a }}$ aproximação). Vitória, SEEA/INCAPER/CEDAGRO. p.111-118.

Machado CTT, Machado AT \& Furlani AC (2004) Variação intrapopulacional em milho para características relacionadas com a eficiência de absorção e utilização de fósforo. Revista Brasileira de Milho e Sorgo, 3:77-91.

Novais RF, Smyth TJ \& Nunes FN (2007) Fósforo. In: Novais RF, Alvarez VH, Barros NF, Fontes RLF, Cantarutti RB \& Neves JCL. (Eds.) Fertilidade do solo. Viçosa, Sociedade Brasileira de Ciência de Solo. p.471-550.

Rotili EA, Fidelis RR, Santos MM, Barros HB \& Pinto LC (2010) Eficiência do uso e resposta à aplicação de fósforo de cultivares de arroz em solos de terras altas. Bragantia, 69:705-710.

Silva L, Marchiori PER, Maciel CP, Machado EC \& Ribeiro RV (2010) Fotossíntese, relações hídricas e crescimento de cafeeiros jovens em relação à disponibilidade de fósforo. Pesquisa Agropecuária Brasileira, 45:965-972.

Shubhra DJ, Goswami CL \& Munjal R (2004) Influence of phosphorus application on water relations, biochemical parameters and gum content in cluster bean under water deficit. Biologia Plantarum, 48:445-448.

Tomaz MA, Martinez HEP, Rodrigues WN, Ferrari, RB, Pereira AA \& Sakiyama NS (2011) Eficiência de absorção e utilização de boro, zinco, cobre e manganês em mudas enxertadas de cafeeiro. Revista Ceres, 58:108-114.

Torres-Netto A, Campostrini E, Oliveira, JG \& Bressan-Smith RE (2005) Photosynthetic pigments, nitrogen, chlorophyll a fluorescence and SPAD-502 readings in coffee leaves. Scientia Horticulturae, 104:199-209. 